\title{
THE INFLUENCE OF MARKETING PUBLIC RELATION TOWORD AND THE WORD OF MOUTH COMMUNICATION (ON STUDY OF THE TOURIST OBJECT TAMAN SAFARI INDONESIA BOGOR)
}

\author{
Dr. Sukmadi, MM \\ Dr. Atang Sabur, M.Pd \\ Sekolah Tinggi Pariwisata Bandung \\ Bandung, Indonesia
}

\begin{abstract}
This study was conducted to determine and analyze (1) the application of marketing public relations, (2) word of mouth communication on attraction Taman Safari Indonesia, (3) the influence of marketing public relations to word of mouth communication.

The method used is quantitative with the type of explanatory research, which would explain the causal relationship between the independent variables on the dependent variable through hypothesis testing. This type of research is composed of descriptive and verification are implemented through data collection in the field. Data collection methods used in the form of a questionnaire, while the study sample is being travelers who happened to meet with investigators while being traveled visiting Indonesian safari park totaling 46 people. This study used a descriptive analysis of the frequency and method of simple linear regression.

Based on the survey results revealed that (1) Marketing public relations are conducted by managers attraction Taman Safari Indonesia has done well. Marketing public relations is done through publications, events, sponsorship, news, speeches, public services and identity media activities, (2) Word of mouth communication is carried out by tourists can help disseminate information about attractions quickly. Travelers give recommendations on the other side of attractions Taman Safari Indonesia, telling positive things and encourage and influence others to visit the attraction in question, (3) There is a significant positive effect between marketing and public relations to the word of mouth communication. This shows the better marketing public relations the better the word of mouth communication about the attraction.
\end{abstract}

Keywords: Marketing Public Relations, Word Of Mouth Communication

\section{INTRODUCTION}

The tourism sector has an important role in the Indonesian economy, both as a source of foreign exchange earnings and employment opportunities and business opportunities. Besides the development of the tourism sector in a region may trigger the development of other sectors, such as agriculture, livestock, crops, and other crafts. It is no exaggeration considering Indonesia's tourism potential is quite large, and many of them have not been optimally used especially regarding the nature tourism, special interest tourism and cultural tourism. Tourism is one of the mainstay industries must continue to be cultivated by a country. This is due in addition to proven to significantly contribute to foreign exchange, can also expand employment opportunities and equitable distribution of the population Agusnawar, 2002). Foreign exchange for a country is a very important factor, especially for developing countries that are implementing the enactment development. With the otonomical regions, where each region is obliged to take care of household affairs alone, almost all regions in Indonesia are racing to introduce the uniqueness, wealth (whether natural, cultural, and man-made) and the hallmark of the region in order to attract tourists to visit.

One of the tourist destination that has tourism potential which needs to be developed is the Taman Safari Indonesia. Taman Safari Indonesia in located in Bogor Regency built for the purpose as a natural attraction. To increase tourist visits to Taman Safari Indonesia, we need a promotion. Promotion is an important thing in the development of tourism. One of the promotional tools that can be done is through marketing public relations. Marketing Public Relations (MPR) is the process of planning, implementing and evaluating programs that encourage the purchase and visitor satisfaction by communicating credible information and impressions. As well as advertising, public relations (PR) is also becoming an important marketing tips. MPR adds value to integrated marketing communications program in several ways, namely building market appeal before the rise of advertising in the media, for example, news about a new product which is an opportunity for marketers to get publicity and dramatize the product that will increase the effectiveness of these ads. 
Recognizing the importance of the role of the Assembly in order to create word of mouth communication is positive for the company, then the Assembly should be able to be a good informant for the company. In addition, MPR practitioner should also be responsive to observe, learn, and solve a problem, both problems that arise from within and from outside the company. MPR will understand the condition of the company, if the company provides the opportunity for the Assembly to accept input, process it, and then integrate it with the program of the company. It is intended that the Assembly can provide impartial information, communicative, and educational for the external public.

Nevertheless, the implementation of the marketing strategy of public relations at the visitor attraction Taman Safari Indonesia allegedly not yet optimal. That is because a lack of promotion by attraction, resulting in performance marketing public relations is not as expected. Other than that, the lack of publicity conducted by the attraction of the potential that exists to cause maximal attraction marketing public relations performance. It is therefore necessary measures to overcome these problems. Basically Marketing public relations done well will be able to create word of mouth communication is positive.

Nowadays the power of word of mouth began to be realized and utilized by many companies, given the advertisements in the mass media is no longer effective as a promotional tool because consumers can only remember five to seven ads per day (Schiffman and Kanuk, 2008). Word of mouth is more trustworthy than by a sales person, and can reach consumers faster than advertising or direct mail, word of mouth because of the strength lies in its ability to provide a recommendation (referral). This is in line with what is stated Dye (2000) that in everyday life people glad to share his experience about something. Thus the word of mouth communication is a non-formal means of communication has an important role in increasing tourist visits to certain attractions.

Problems related to word of mouth communication is generally word of mouth communication travelers who do not yet effective in increasing tourist arrivals on the relevant attraction. This is because the quantity of communication will be undertaken by tourists on others is minimal, the level of recommendation by tourists to visit the attraction is still lacking and there is a negative impression which the attraction is not maintained clean so hinder the effectiveness of word of mouth communication performance itself.

Based on the above, this study has several objectives are as follows:

1. To identify and analyze marketing public relations at Taman Safari Indonesia attraction.

2. To find out and analyze the word of mouth communication on attraction Taman Safari Indonesia.

3. To determine and analyze the effect of marketing public relations to word of mouth communication on attraction Taman Safari Indonesia.

\section{RESEARCH METHODS}

Research on the influence of public relations with marketing word of mouth communication is a quantitative study type explanatory research, which would explain the causal relationship between the independent variables on the dependent variable through hypothesis testing. This type of research is composed of descriptive and verification are implemented through data collection in the field.

The data collection techniques by the author in this study are (1) observation, (2) Interview, (3) questionnaire. While the data analysis consisted of descriptive and verification with regression. In this study, there is one dependent variable and one independent variable.

Under these conditions, the method of analysis used is a simple regression, the equation can be expressed as follows:

$\mathrm{Y}=\mathrm{a}+\mathrm{bX}+\mathrm{e}$

Information:

$\mathrm{Y}=\mathrm{WOM}$

$\mathrm{X}=M P R$

$\mathrm{a}=$ regression konstanta

$\mathrm{b}=$ regression koefisien

$\mathrm{e}=$ error 


\section{RESULTS AND DISCUSSION}

\section{A. Descriptive overview of Research Data}

Data respondents described the results in the form of an image to determine the proportion of respondents in each of the statement is then interpreted in accordance with the underlying theories.

\section{Results of Descriptive Analysis Marketing Public Relations}

The results of a study on 16 respondents' answers to questions in the questionnaire marketing public relations as follows:

Table 1

Frequency Response Marketing Public Relations

\begin{tabular}{|c|c|c|c|c|c|c|}
\hline \multirow{2}{*}{ No. } & \multicolumn{7}{|c|}{ Frequency response } & \multirow{2}{*}{ Total } \\
\cline { 2 - 5 } & $\mathbf{5}$ & $\mathbf{4}$ & $\mathbf{3}$ & $\mathbf{2}$ & $\mathbf{1}$ & \\
\hline $\mathrm{p} 1$ & 13 & 22 & 3 & 5 & 3 & $\mathbf{4 6}$ \\
\hline $\mathrm{p} 2$ & 5 & 24 & 8 & 7 & 2 & $\mathbf{4 6}$ \\
\hline $\mathrm{p} 3$ & 5 & 35 & 2 & 2 & 2 & $\mathbf{4 6}$ \\
\hline $\mathrm{p} 4$ & 7 & 17 & 12 & 8 & 2 & $\mathbf{4 6}$ \\
\hline $\mathrm{p} 5$ & 8 & 23 & 9 & 4 & 2 & $\mathbf{4 6}$ \\
\hline $\mathrm{p} 6$ & 10 & 22 & 5 & 7 & 2 & $\mathbf{4 6}$ \\
\hline $\mathrm{p} 7$ & 13 & 24 & 3 & 4 & 2 & $\mathbf{4 6}$ \\
\hline $\mathrm{p} 8$ & 2 & 23 & 13 & 5 & 3 & $\mathbf{4 6}$ \\
\hline $\mathrm{p} 9$ & 11 & 22 & 3 & 7 & 3 & $\mathbf{4 6}$ \\
\hline $\mathrm{p} 10$ & 10 & 18 & 5 & 9 & 4 & $\mathbf{4 6}$ \\
\hline $\mathrm{p} 11$ & 14 & 23 & 4 & 5 & 0 & $\mathbf{4 6}$ \\
\hline $\mathrm{p} 12$ & 4 & 26 & 7 & 9 & 0 & $\mathbf{4 6}$ \\
\hline $\mathrm{p} 13$ & 5 & 28 & 8 & 3 & 2 & $\mathbf{4 6}$ \\
\hline $\mathrm{p} 14$ & 7 & 18 & 13 & 8 & 0 & $\mathbf{4 6}$ \\
\hline $\mathrm{p} 15$ & 9 & 23 & 10 & 4 & 0 & $\mathbf{4 6}$ \\
\hline $\mathrm{p} 16$ & 10 & 21 & 5 & 10 & 0 & $\mathbf{4 6}$ \\
\hline Total & $\mathbf{1 3 3}$ & $\mathbf{3 6 9}$ & $\mathbf{1 1 0}$ & $\mathbf{9 7}$ & $\mathbf{2 7}$ & $\mathbf{7 3 6}$ \\
\hline No. & & & Score Answers & & Total \\
\cline { 2 - 6 } & $\mathbf{5}$ & $\mathbf{4}$ & $\mathbf{3}$ & $\mathbf{2}$ & $\mathbf{1}$ & \\
\hline $\mathrm{i} 1$ & 65 & 88 & 9 & 10 & 3 & $\mathbf{1 7 5}$ \\
\hline $\mathrm{i} 2$ & 25 & 96 & 24 & 14 & 2 & $\mathbf{1 6 1}$ \\
\hline $\mathrm{i} 3$ & 25 & 140 & 6 & 4 & 2 & $\mathbf{1 7 7}$ \\
\hline $\mathrm{i} 4$ & 35 & 68 & 36 & 16 & 2 & $\mathbf{1 5 7}$ \\
\hline $\mathrm{i} 5$ & 40 & 92 & 27 & 8 & 2 & $\mathbf{1 6 9}$ \\
\hline $\mathrm{i} 6$ & 50 & 88 & 15 & 14 & 2 & $\mathbf{1 6 9}$ \\
\hline $\mathrm{i} 7$ & 65 & 96 & 9 & 8 & 2 & $\mathbf{1 8 0}$ \\
\hline $\mathrm{i} 8$ & 10 & 92 & 39 & 10 & 3 & $\mathbf{1 5 4}$ \\
\hline $\mathrm{i} 9$ & 55 & 88 & 9 & 14 & 3 & $\mathbf{1 6 9}$ \\
\hline $\mathrm{i} 10$ & 50 & 72 & 15 & 18 & 4 & $\mathbf{1 5 9}$ \\
\hline $\mathrm{i} 11$ & 70 & 92 & 12 & 10 & 0 & $\mathbf{1 8 4}$ \\
\hline $\mathrm{i} 12$ & 20 & 104 & 21 & 18 & 0 & $\mathbf{1 6 3}$ \\
\hline $\mathrm{i} 13$ & 25 & 112 & 24 & 6 & 2 & $\mathbf{1 6 9}$ \\
\hline $\mathrm{i} 14$ & 35 & 72 & 39 & 16 & 0 & $\mathbf{1 6 2}$ \\
\hline $\mathrm{i} 15$ & 45 & 92 & 30 & 8 & 0 & $\mathbf{1 7 5}$ \\
\hline $\mathrm{i} 16$ & 50 & 84 & 15 & 20 & 0 & $\mathbf{1 6 9}$ \\
\hline Total & $\mathbf{6 6 5}$ & $\mathbf{1 4 7 6}$ & $\mathbf{3 3 0}$ & $\mathbf{1 9 4}$ & $\mathbf{2 7}$ & $\mathbf{2 3 4 8}$ \\
\hline & & & \multicolumn{2}{|c}{} \\
\hline
\end{tabular}


To categorize respondents to the questionnaire assessment of marketing public relations, in accordance of the answers above, the writer makes the categorization in line interval as follows:

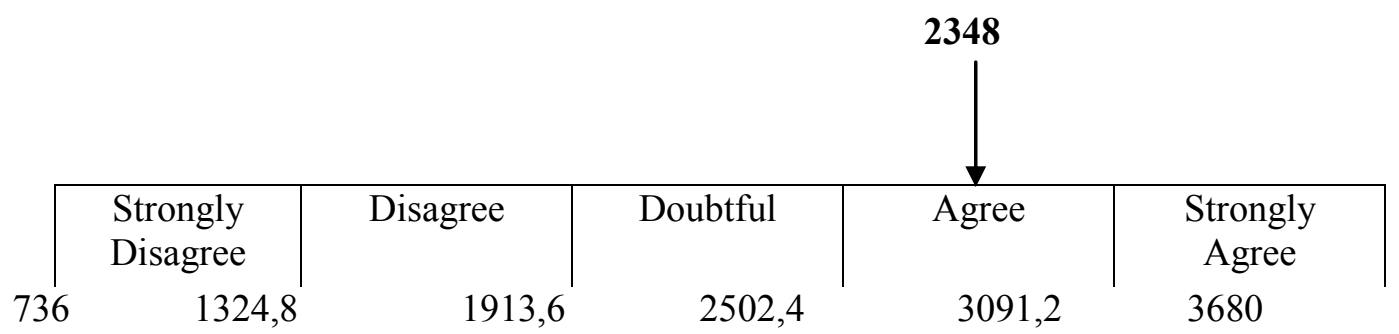

The total score of the sixteen items above questions obtained a total score of 2348 in the category "Agree". The results of this study indicate that marketing is carried out by the public relations manager of attraction Taman Safari Indonesia has done well. Marketing public relations is done through publications, events, sponsorship, news, speeches, public services and identity media activities. Media publications made to reach and influence your target market and performed through a variety of media including brochures, articles and magazine companies. Taman Safari Indonesia attractions also doing events to attract tourists to visit the attraction. Through these events can help spread information more effectively right on target.

In the sponsorship attraction promoting corporate identity by responding to sporting events and arts events. Through this sponsorship helps facilitate the existence of promotional activities undertaken by the attraction. Business attraction attractions also informed through the news clearly that the information provided can be well received by tourists visiting the attraction. News about this attraction is done through a variety of print and electronic media. Besides that, attraction manager gave a speech to tourists with clear and accurate so that the information provided by the manager of attraction can be well understood.

To further enhance the effectiveness of marketing manager attraction perform public service activities to the tourists visiting the tourist attraction. Public service activities performed in order to obtain a favorable impression attraction of tourists and it helps in introducing the attraction of tourists. Marketing public relations are conducted by managers of attractions equipped with logos and slogans as a corporate identity that is expected to be known by the public. The identity of the company that was introduced to the travelers have a clear identity so easily recognized by the public.

\section{Results of Descriptive Analysis Word of Mouth Communication}

The results of a study on 9 respondents' answers to questions in the questionnaire word of mouth communication as follows:

Table 2

Frequency Answer of Word of Mouth Communication

\begin{tabular}{|c|c|c|c|c|c|c|}
\hline \multirow[t]{2}{*}{ No. } & \multicolumn{5}{|c|}{ Frequency Response } & \multirow[t]{2}{*}{ Total } \\
\hline & 5 & 4 & 3 & 2 & 1 & \\
\hline $\mathrm{p} 1$ & 10 & 27 & 6 & 3 & 0 & 46 \\
\hline p2 & 10 & 21 & 8 & 7 & 0 & 46 \\
\hline p3 & 2 & 38 & 4 & 2 & 0 & 46 \\
\hline $\mathrm{p} 4$ & 2 & 23 & 15 & 6 & 0 & 46 \\
\hline $\mathrm{p} 5$ & 14 & 23 & 4 & 5 & 0 & 46 \\
\hline p6 & 0 & 34 & 10 & 2 & 0 & 46 \\
\hline p7 & 4 & 33 & 7 & 2 & 0 & 46 \\
\hline $\mathrm{p} 8$ & 15 & 22 & 4 & 5 & 0 & 46 \\
\hline p9 & 5 & 27 & 10 & 4 & 0 & 46 \\
\hline Total & 62 & 248 & 68 & 36 & 0 & 414 \\
\hline
\end{tabular}




\begin{tabular}{|c|c|c|c|c|c|c|}
\hline \multirow{2}{*}{ No. } & \multicolumn{5}{|c|}{ Score Answer } & \multirow{2}{*}{ Total } \\
\cline { 2 - 6 } & $\mathbf{5}$ & $\mathbf{4}$ & $\mathbf{3}$ & $\mathbf{2}$ & $\mathbf{1}$ & \\
\hline $\mathrm{i} 1$ & 50 & 108 & 18 & 6 & 0 & $\mathbf{1 8 2}$ \\
\hline $\mathrm{i} 2$ & 50 & 84 & 24 & 14 & 0 & $\mathbf{1 7 2}$ \\
\hline $\mathrm{i} 3$ & 10 & 152 & 12 & 4 & 0 & $\mathbf{1 7 8}$ \\
\hline $\mathrm{i} 4$ & 10 & 92 & 45 & 12 & 0 & $\mathbf{1 5 9}$ \\
\hline $\mathrm{i} 5$ & 70 & 92 & 12 & 10 & 0 & $\mathbf{1 8 4}$ \\
\hline $\mathrm{i} 6$ & 0 & 136 & 30 & 4 & 0 & $\mathbf{1 7 0}$ \\
\hline i7 & 20 & 132 & 21 & 4 & 0 & $\mathbf{1 7 7}$ \\
\hline i8 & 75 & 88 & 12 & 10 & 0 & $\mathbf{1 8 5}$ \\
\hline i9 & 25 & 108 & 30 & 8 & 0 & $\mathbf{1 7 1}$ \\
\hline Total & $\mathbf{3 1 0}$ & $\mathbf{9 9 2}$ & $\mathbf{2 0 4}$ & $\mathbf{7 2}$ & $\mathbf{0}$ & $\mathbf{1 5 7 8}$ \\
\hline
\end{tabular}

To categorize respondents to the questionnaire assessment of word of mouth communication, in accordance of the answers above, the writer makes the categorization of the line interval as follows:

1578

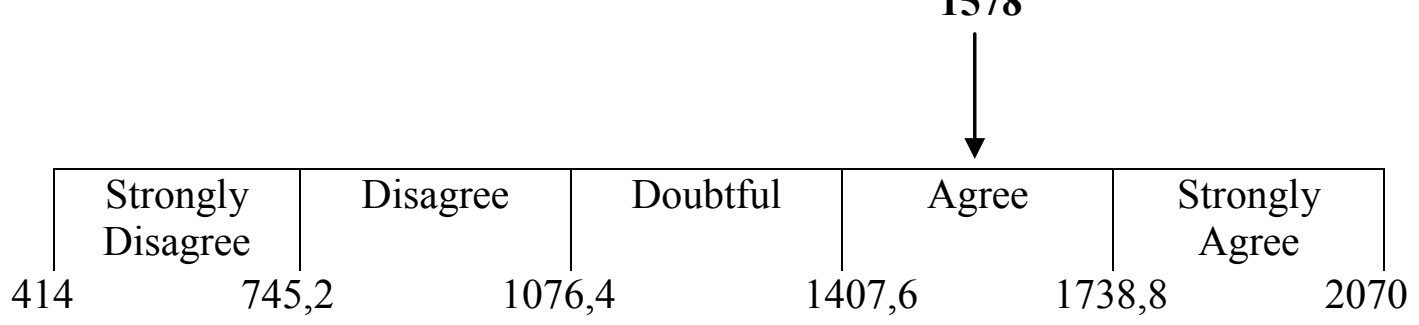

Score a total of nine items above questions obtained a total score of 1578 in the category "Agree". This suggests that travelers always have a positive outlook of attractions. The positive outlook is always spread by word of mouth communication positive traveler who has visited the attraction on the other side. In the daily conversation travelers often mention the name of Taman Safari Indonesia thus well remembered in the minds of tourists. Then frequent travelers on Taman Safari Indonesia discussion with others so that the other party is very curious to visit the attraction.

Level recommendations made by travelers to other parties very intensive. It is very helpful to the promotion by attraction to attract tourists to visit the attractions recommended by the other party. Travelers also told positive things to others so that it will form a positive image of the attractions visited by tourists. Furthermore, attraction can also form beliefs tourists to visit Taman Safari Indonesia making travelers interested in the attraction.

The results of subsequent studies showed that tourists always invite and persuade other tourists to visit in the attraction and encourage others to go on holiday to Taman Safari Indonesia. This is because the tourists who have visited attraction obtain satisfaction after visiting the attractions both in terms of services and events organized by attraction. The tourists also always influence others to visit the attraction Taman Safari Indonesia because it is. Then the tourists also want others to be able to enjoy all the facilities and amenities provided by the Indonesian Safari Park attractions. That is because travelers have a positive perception of attraction is concerned.

\section{B. Regression Results Analysis}

The results of multiple linear regression analysis using SPSS ver 15 for windows intended to analyze the influence of the variables on the Assembly of the WOM is to see a large coefficient of determination (R Square). In this study, there was 1 (one) dependent variable and one (1) independent variables. Under these conditions, the method of analysis used is a simple regression. From the regression analysis is performed using SPSS ver 15 for windows, if the results of the data might look like table 3 follows: 
Table 3

Regresion Analysis

\begin{tabular}{|l|l|r|r|r|r|r|}
\hline \multirow{2}{*}{ Model } & \multicolumn{2}{|c|}{$\begin{array}{c}\text { Unstandardized } \\
\text { Coefficients }\end{array}$} & $\begin{array}{l}\text { Standardized } \\
\text { Coefficients }\end{array}$ & \multirow{2}{*}{ t } & \multirow{2}{*}{ Sig. } \\
\cline { 3 - 5 } \multicolumn{2}{|c|}{} & \multicolumn{1}{|c|}{ B } & Std. Error & Beta & & \\
\hline 1 & (Constant) & 63,936 & 9,183 & & 6,962 &, 000 \\
\hline & MPR &, 669 &, 156 &, 604 & 4,290 &, 000 \\
\hline
\end{tabular}

a Dependent Variable: WOM

Based on the above table, the regression equation in the can are as follows:

$\mathrm{Y}=63,936+0,669 \mathrm{X}$

Keterangan :

$\mathrm{Y}=\mathrm{WOM}$

$\mathrm{X} \quad=$ MPR

The above equation mathematical model shows that the effect on the public relations marketing word of mouth communication. It was evident from the regression coefficient is positive 0.669 risk management. 3

Based on the above table, it can be seen that the significance probability value or $p$ value is 0.000 or the smaller of 0.05 or $5 \%$ and the regression coefficient is positive 0.669 , which means the hypothesis of marketing public relations positive and significant effect on the word of mouth communication can be proved.

While the ability to measure how far the independent variables in explaining the variables that are bound to use test R2 coefficient of determination of prices. Calculation if the data SPSS regression results are shown in Table 4. the following:

Table 4

Coefficient Determination

\begin{tabular}{|l|r|r|r|r|}
\hline Model & \multicolumn{1}{|c|}{ R } & R Square & $\begin{array}{c}\text { Adjusted } \\
\text { R Square }\end{array}$ & $\begin{array}{c}\text { Std. Error } \\
\text { of the } \\
\text { Estimate }\end{array}$ \\
\hline 1 &, $604(\mathrm{a})$ &, 365 &, 345 & 6,30832 \\
\hline
\end{tabular}

a Predictors: (Constant), MPR

Based on the model of SPSS output display summary, the magnitude of the adjusted R2 is 0.345 , meaning $34.5 \%$ of dependent variables of word of mouth communication can be explained or influenced by the independent variables of marketing public relations, while the remaining $64.5 \%(100 \%-34.5 \%)$ is explained by reasons other than this model.

\section{Discussion of Results Research}

The results showed that marketing public relations undertaken by managers attraction Taman Safari Indonesia has done well. Marketing public relations managers conducted by Taman Safari Indonesia attraction through publications, events, sponsorship, news, speeches, public services activities, and identity media. Marketing public relations is one of the ways of the six main ways of communication are very important marketing role and duties. Marketing is a public relations planning, implementation and evaluation of programs that can stimulate purchases and customer satisfaction through the communication of reliable information and through positive impressions generated and associated with the identity of the company or its products according to the needs, desires, concerns and interests for consumers (Rosady Ruslan, 2006:245).

Creative marketing public relations can affect public awareness at a cost that is far less than the cost of advertising. The company does not pay for the space and time obtained in the media . The company only pays a staff member to compile and circulate the stories and manage certain events. The role of marketing public relations in an effort to achieve its goals in outline is to build consumer awareness of the products offered, build trust, encourage purchases, reduce the cost of the promotion and effective in the face of a situation or event giving rise to the negative perception that efforts to restore the negative perception can be done with proper and good relationships with various public companies can be maintained. Under these conditions, marketing public relations is very important to promote attractions to potential tourists.

Meanwhile, word of mouth communication is carried out by tourists can help disseminate information about attractions quickly. Travelers always have a positive outlook of attractions. This positive outlook is 
always spread by word of mouth communication positive traveler who has visited the attraction on the other side so it is very effective as a tool in promoting attractions. WOM has a greater strength than advertising or direct sales because WOM strength lies in its ability to provide a recommendation (referral). WOM received special attention from consumers because it is perceived as credible and deliver WOM considered only provide information and share their experiences in consuming a product/service without having any interest on the sales of products/services George ( 2001:25).

Another reason why WOM very important role in the marketing of a product is because WOM can increase the speed of product purchasing decisions. WOM make the process faster, because what is discussed in the WOM based on experience of the product or service so that consumers will tend to believe it.

The results of subsequent studies showed that there is a positive and significant effect between marketing public relations to word of mouth communication. This can be seen from the value of the probability of significance (sig.) or the p value of 0.000 or less than $0.05(5 \%)$ and regressinya coefficient is 0.669 . The results of the study in accordance with that stated by Mechinda (2010:222) who states competitiveness factors and the number of tourist destinations positive effect on loyalty and word of mouth travelers heading Koh Chang (Chang Island). From the results of this research are very clear that competitiveness factors have an influence on word of mouth so that travelers will be formed tourist perceptions of a particular attraction. In line with these two Urosovic (2010:1315) states that cultural tourism, destination marketing and marketing strategy through the development of public relations has a positive effect on word of mouth of cultural tourism. Therefore, there is a link between marketing public relations by word of mouth communication. From these results it is known that the dimension of marketing and public relations as news publications intense, simultaneous and continuous to a tourist destination was able to give travelers the confidence and commitment to the tourist destination so as to create word of mouth from travelers to tourist destinations the traveler who makes the connection between the image of the destination is increased and better quality.

\section{A. Conclusions}

\section{CONCLUSIONS AND RECOMMENDATIONS}

Based on the results of research conducted to determine the effect of marketing public relations to word of mouth communication as well as the foregoing discussion, it can be drawn some conclusions as follows:

1. Marketing public relations are conducted by managers attraction Taman Safari Indonesia has done well. Marketing public relations is done through publications, events, sponsorship, news, speeches, public services and identity media activities.

2. Word of mouth communication is carried out by tourists can help disseminate information about attractions quickly. Travelers give recommendations on the other side of attractions Taman Safari Indonesia, telling positive things and encourage and influence others to visit the attraction in question.

3. There is a significant positive effect between marketing and public relations to the word of mouth communication. This shows the better marketing public relations the better the word of mouth communication about the attraction.

\section{B. Recommendations}

Based on the above conclusion of the study, the authors present some suggestions for the parties relating to this study are as follows:

1. Marketing public relations are conducted by attraction managers need to consider the appropriate medium to promote the attraction to tourists in order to better targeted.

2. Attraction manager should change the negative perception of tourists not argued about the negative things that exist on the attractions visited on others such disclosure to others that certain attractions are considered unsafe and not good and no security guarantee attraction visited through the provision of a positive image and security guarantees provided by the manager of attraction.

3. There needs to be cooperation between local governments, and community managers attractions surrounding area to develop a better tourism again. 


\section{BIBLIOGRAPHY}

Agus Nawar. 2002. Psikologi Pelayanan. Bandung : Alfabeta.

Belch, George E., and Belch. Michael A. 2009. Advertising and Promotion: An Integrated, Mark.

Blackwell, R. D. 2001. Customer behaviour (9 th ed). Orlando: Hardcourt. College.

Dye, Renee. 2000. The Buzz on Buzz. Harvard Business Review, 78 (6).

Godes,David dan Dina Mayzlin. 2004. Using Online Conversations to Study Word of Mouth Communication. Marketing Science. Vol. 23 No. 4.

Grunig, James E., dan Larissa E. Grunig. 2008. Models of Public Relations and Communication dalam Excellence in Public Relations and Communication Management. Jakarta: New Jersey: Lawrence Erlbaum Associates, Inc.

Harris, Thomas L. 2008. The Marketers Guide To Public Relations. New York: John. Wiley \& Sons, Inc.

Indriantoro dan Supomo. 2009. Metodologi Penelitian Bisnis. Yogyakarta, BPFE-Yogyakarta

Jang, Dongsuk. 2003. Effect of word of mouth communication on purchasing decession in resstarant. Dissertation. Las vegas University of Nevada

Kaplanidou, Kiki. 2009. The role of word-of-mouth and how it can be used to develop a competitive advantage for a destination. Journal Travel Michigan and MSU Department of Park, Recreation and Tourism Resources

Malholtra, Naresh. 2010. Marketing Research An Applied Orientation. Six Edition.Prentice Hall

Matos. 2008. Word-of-mouth communications in marketing: a meta-analytic review of the antecedents and moderators. Journal Marketing Department, School of Management, Federal University of Rio Grande do Sul

Ruslan, Rosady. 2006. Kiat dan Strategi Kampanye Public Relations (Revisi). Jakarta: Raja Grafindo Persada.

Schiffman, Leon, \& Kanuk, Leslie Lazar. 2008. Consumer Behaviour 7 th. Edition. (Perilaku Konsumen). Jakarta: PT. Indeks.

Sekaran, Uma. 2003. Research Methods for Business. USA: John Wiley \& Sons, Inc.

Shimp, Terence. 2009. Periklanan Promosi. Jakarta : Erlangga.

Sugiyono. 2008. Metode Penelitian Bisnis. Bandung : Alfabeta

Tercia, Ch. Yosevina Ratna. 2008. Sikap Kewirausahaan dan Orientasi Pelanggan: Implikasinya terhadap Kinerja Tenaga Penjualan, Manajemen Usahawan Indonesia, No. 04, TH. XXXVII 2008.

Umar, Husen. 2002. Metode Penelitian. Jakarta : Salemba Empat

Woznaik. 2001. Consumer Behavior and Applied Approach. Prentice Hall: New Jersey 